\title{
TRZYNASTOWIECZNA TRADYCJA MISTYCZNA W BAROKOWYM OBRAZIE ADORACJI RAN CHRYSTUSA PRZEZ ZAKONNICE REGUEY ŚW. BENEDYKTA Z KLASZTORU PANIEN BENEDYKTYNEK W PRZEMYŚLU
}

W 1616 r. w Przemyślu, poza murami miejskimi, przy przeprawie na lewym brzegu Sanu, na styku traktów węgierskiego i krakowskiego, została zakończona budowa kościoła Świętej Trójcy. Ufundował go ks. Maciej Wołkowicz, proboszcz katedry przemyskiej, wspomagany finansowo przez miejscowych mieszczan. W założeniu miał to być kościół filialny katedry przemyskiej dla wiernych, którzy mieszkając za Sanem, nie mogli przychodzić na nabożeństwa w czasie częstych przyborów wody w tej rzece. Po bezskutecznych próbach sprowadzenia do kościoła przedstawicieli któregoś z męskich zakonów, w 1618 r. ks. Wołkowicz przekazał kościół, zabudowania gospodarcze i niewielki grunt, za zgodą biskupa przemyskiego Stanisława Sobiecińskiego, benedyktynkom z Jarosławia (Hauser 216-217; Gosztyła i Proksa 15, 16). Pierwsze siostry przybyły jednak dopiero w 1626 r. Formalnie objęły tę placówkę trzy lata później. Prawdopodobnie dopiero wówczas zakończono budowę drewnianego budynku klasztornego, a także przystosowywanie kościoła dla celów zakonnych. Klasztor przemyski był filią jarosławskiego do 1694 r., kiedy to decyzją biskupa przemyskiego Jerzego Albrechta Denhoffa rozłączono dwa konwenty, podnosząc przemyski do rangi opactwa. W ciągu XVII wieku zostały wzniesione murowane budynki, które stanowiły zrąb obecnego klasztoru (Katalog Zabytków Sztuki w Polsce 106, 114).

Zakon Panien Benedyktynek był pierwszym zgromadzeniem żeńskim na terenie diecezji przemyskiej. Był też pierwszym, który odrodził się na ziemiach polskich w duchu Soboru Trydenckiego, pod naporem nowych sił,

Dr hab. Bożena KuklińsKa, prof. KUL - Katolicki Uniwersytet Lubelski Jana Pawła II, Wydział Nauk Humanistycznych, Instytut Nauk o Sztuce, Katedra Badań nad Sztuką od Starożytności do Nowoczesności; adres do korespondencji: Al. Racławickie 14, 20-950 Lublin; e-mail: b.kuklinska@vp.pl; ORCID: https://orcid.org/0000-0002-8659-1221. 
oddających się z zapałem idei doskonałości chrześcijańskiej. Odrodzenie zaczęło się od klasztorów żeńskich reguły św. Benedykta. Było ono dziełem Magdaleny Mortęskiej, jednej z czołowych postaci potrydenckiego katolicyzmu w Polsce (Górski, Od religijności do mistyki 70). Ksieni obsadziła osiem innych podupadłych lub nowych fundacji, które fundowały dalej. Powstało ponad dwadzieścia klasztorów benedyktynek, z których wywodzą się wszystkie inne wspólnoty poza istniejącym wcześniej klasztorem w Staniątkach. Mortęska oparła duchowość zreformowanego klasztoru panien benedyktynek na pracy intelektu. Spisywano medytacje, dyskutowano je, korygowano. Tak było też $\mathrm{w}$ innych klasztorach panien benedyktynek. Podobnie jak Ignacy Loyola, podstawy swojej szkoły duchowości zaczerpnęła u benedyktynów, zreformowanych w końcu XV wieku przez Garcię Ximeneza. Religijność potrydencka ukazała większe niż u schyłku średniowiecza zaangażowanie kobiet w odrodzenie życia monastycznego oraz udział kobiet w odnowie życia mistycznego (Borkowska, „Magdalena Mortęska” 12, 13; Mróz 19, 20).

Fundatorką jarosławskiego klasztoru była ówczesna właścicielka Jarosławia Anna ze Stembergu, księżna Ostrogska. Sprowadziła ona mniszki z klasztoru w Chełmnie, gdzie ksienią była jej kuzynka, Magdalena Mortęska, która zdecydowała się ostatecznie na otwarcie domu w Jarosławiu. Nowy konwent został hojnie wyposażony przez macierzysty klasztor w księgi łacińskie i polskie, szaty, pościel i inne potrzebne rzeczy, które na szkutach księżnej popłynęły do Jarosławia (Szołdrski 127). W 1613 r. jej fundacja została zatwierdzona przez biskupa przemyskiego Stanisława Siecińskiego i przez kapitułę przemyską. Konwent jarosławski dzięki swojemu majątkowi należał do najbogatszych klasztorów benedyktynek w kraju. Posiadał też najbogatszą bibliotekę (Borkowska, Zakony żeńskie w Polsce 265-268). Reguła benedyktyńska kładła nacisk na ubóstwo osobiste mniszek, ale nigdy nie zakładała ubóstwa zbiorowego (Kieferling 194, 200).

Także konwent przemyski został hojnie uposażony, a był to czas, gdy po reformie chełmińskiej klasztory benedyktynek zaczęły przyciągać powołania panien z rodzin magnackich, zamożnej szlachty i mieszczan. Tak odnotował to ojciec Brzechffa w żywocie Magdaleny Mortęskiej (Brzechffa):

ze wszystkich prawie stron Polski zacnych rodziców córki kupami się garnęły, które porzuciwszy świata tego marności, niebieskiemu Oblubieńcowi swemu poślubić się pragną. (Górski, Pisma ascetyczno-mistyczne 42)

Wraz z pannami z dobrych domów przybywały środki na utrzymanie i rozmaite darowizny. Kościół, szczególnie ten nowy, wybudowany w latach 1768- 
1777 z fundacji Franciszka Potockiego (Hauser 216-217), i klasztor otrzymały bogaty wystrój i wyposażenie, które w części zachowało się do naszych czasów. Tak o ozdobie Domu Bożego pisze siostra Małgorzata Borkowska:

Ale właściwym terenem ich dbałości o ozdobę domu Bożego było wyposażenie $\mathrm{i}$ te wszystkie gałęzie sztuki, które składały się na piękno liturgii oraz estetykę życia codziennego.[...] Dla ludzi baroku było bowiem nie do pojęcia, jak można podczas Mszy św. położyć Ciało Pańskie na glinianym, na przykład, albo nawet i miedzianym, a nie pozłacanym naczyniu. [...] Idąc dalej, należało i szaty liturgiczne, i wnętrze kościoła mieć tak ozdobne, jak tylko środki materialne pozwalały: to było swoistym wyznaniem wiary. Ozdoba zaś w owej epoce łączyła dwa pojęcia: sztuki i bogactwa. Nie wystarczało ani samo bogactwo, ani sama sztuka. (Borkowska, Życie codzienne 124-125)

Ojciec Placyd Galiński tak tłumaczy ten estetyzm religijny:

[...] mnisi starają się nadać cechę piękna miejscom, rzeczom i przedmiotom kultu, a nawet życia codziennego, ale korzenie tego starania są inne niż „estetyka”. One tkwią w przeżywaniu piękna Stwórcy, Jego działania wśród ludzi przez historię zbawienia, wreszcie w ładzie duchowym człowieka zdążającego pewną drogą ku Bogu. (Galiński 36)

W kręgach benedyktyńskich sztuka zajmowała zawsze istotne i wartościowe miejsce oraz doceniano jej rolę w wielu aspektach życia człowieka wierzącego. W znanym traktacie Diversarum Artium Schedula jego autor, benedyktyński mnich Teofil Prezbiter, który żył na przełomie XI i XII wieku, zawarł swoje przemyślenia na temat sztuk pięknych i potrzeby dekoracyjności oraz bogatego wystroju wnętrza świątyni, która ma przypominać niebieską ojczyznę - doskonały świat niewidzialny (Kobielus 246-261; Teofil Prezbiter).

Dzieła sztuki, zwłaszcza te, które powstawały w okresie baroku, stanowią dla nas przekaz bogaty w odniesienia i różnorakie znaczenia, które były jasne dla żyjącego wówczas odbiorcy, natomiast dla współczesnego badacza stanowią często niejasne zagadki. Owa sztuka wyraża prawdy teologiczne, moralne czy odnoszące się do duchowości zakonnej. Sztuka baroku ukazuje skomplikowaną symbolikę, ciekawą ikonografię, znakomite założenia estetyczne, dzieła bogate w formę, ale również w przekazywaną treść. Wykształciła kanon przedstawień stosowany najczęściej w kościołach klasztornych i propagujący duchowość konkretnego zakonu. Chociaż przedstawienia o takim 
charakterze były znane już w sztuce średniowiecznej; jak Stygmatyzacja św. Franciszka (ok. 1450) czy Nadanie reguty przez św. Augustyna (początek $\mathrm{XV}$ wieku), to jednak dopiero $\mathrm{w}$ malarstwie nowożytnym stały się powszechne (Rotter 128).

$\mathrm{W}$ tym wypadku to doświadczenia mistyczne zapisywane $\mathrm{w}$ średniowiecznych klasztorach, które prezentują część europejskiego dziedzictwa, i wizje rozmodlonych kobiet zainspirowały artystę do ukazania duchowości związanej z zakonami reguły św. Benedykta. To mistyczne dziedzictwo średniowiecza $w$ dziedzinie duchowych uniesień wydało znaczące owoce w XVII stuleciu.

Jednym z ciekawszych barokowych obrazów przechowywanych w przemyskim klasztorze Panien Benedyktynek jest Adoracja ran Chrystusa przez zakonnice reguły św. Benedykta (il. 1.). Został on namalowany około połowy XVII wieku (Katalog Zabytków Sztuki 117, fig. 299) na płótnie. Ma kształt stojącego prostokąta o wymiarach $71 \times 48 \mathrm{~cm}$ (w świetle ramy).

Centrum przedstawienia zajmuje postać Chrystusa, który unosi się, a jednocześnie jest delikatnie podtrzymywany przez stojącą za Nim Maryję oraz pięć sióstr benedyktynek. W prawym górnym rogu widoczny jest, w otwartych niebiosach, Bóg Ojciec i gołębica Ducha Świętego. Tło przedstawienia stanowi ciemna ściana $\mathrm{z}$ dwoma otworami ukazującymi pejzaż miejski i górski. Na pierwszym planie, przed postaciami, widoczna jest ziemia z kępkami trawy i rosnącymi kwiatami.

Chrystus ma na sobie widoczne $\mathrm{w}$ niewielkim fragmencie perisonium i czerwony płaszcz, który okrywa ramiona, plecy i biodra. Na jego pociągłej twarzy zwracają uwagę duże, otwarte oczy i ciemny krótki zarost. $\mathrm{Na}$ ciele są wyraźnie zarysowane mięśnie nóg, rąk i klatki piersiowej. Czerwoną farbą zostały zaznaczone rany nóg, rąk i boku. Lewą dłonią Chrystus podtrzymuje chorągiew zwycięstwa osadzoną na długim drzewcu. Za Chrystusem, widoczna po Jego prawej stronie, stoi Maryja. Ma na sobie niebieski płaszcz, biały maforion i różową suknię. Głowy obu postaci, ukazanych na tle złocistej mandorli, okalają delikatne nimby (il. 2).

Wokół ciała Chrystusa przedstawiono pięć mniszek. Każda z nich przytula twarz do jednej z jego ran. Są ubrane w czarne benedyktyńskie habity z białymi kołnierzami i czarne welony na białym płóciennym podbiciu. Ich głowy otaczają delikatne aureole. Dwie, ukazane u stóp, podtrzymują ciało Chrystusa, wspierając Jego stopy na swoich ramionach. U stóp każdej z zakonnic znajduje się inskrypcja z jej imieniem: S. GERTRUDIS, S. SCHOLASTICA, S. MECHTILDIS, S. LUDGANRDIS [sic!] i S. ALDEGUNDIS. Każda z ma przy sobie koronkę, 
a cztery z nich, poza Scholastyką, księgę. Scholastyka przytula twarz do rany $\mathrm{w}$ boku. Obiema rękami prezentuje koronkę. Przy prawej dłoni Chrystusa klęczy Gertruda. Jej koronka i księga leżą za nią, na parapecie otworu w murze. Do lewej dłoni przytula twarz Ludgarda. Prawą ręką dotyka ręki Chrystusa, lewą, na której ma przewieszoną koronkę, podtrzymuje księgę. Lewą stopę obejmuje obiema rękami klęcząca Aldegunda. Przez jej lewą dłoń jest przewieszona koronka. Jej księga leży na niewielkim, znajdującym się u stóp Chrystusa wzniesieniu, porośniętym trawą. Niemalże symetrycznie do niej została ukazana, przy prawej stopie Chrystusa, Mechtylda z koronką przewieszoną przez prawą dłoń. Jej księga, leżąca na pagórku, jest otwarta (il. 3).

W prawym górnym rogu obrazu zostały ukazane dwie Osoby Trójcy Świętej - Bóg Ojciec, który zasiada na rozświetlonych obłokach w purpurowym płaszczu i błękitnej szacie, z trójkątnym nimbem za głową, prawą ręką podtrzymując kulę zwieńczoną krzyżykiem i berłem w lewej dłoni, z rozwartych zaś niebios ku Chrystusowi spływa gołębica Ducha Świętego (il. 4).

$\mathrm{W}$ tle, z prawej strony, widoczne są wieże budowli sakralnych, dalej być może zamek, a następnie skaliste wzniesienia. Na parapecie leży księga i koronka. Z lewej strony na parapecie prześwitu stoi wazon z kwiatami, a dalej zostały namalowane góry i między nimi liściaste i iglaste drzewa. Malowidło dowodzi sprawnej ręki lokalnego mistrza.

Obraz ukazuje skomplikowane, ale znakomicie powiązane z sobą treści. Przede wszystkim przywodzi na myśl wywodzące się ze średniowiecza przedstawienie Misericordia Domini lub Męża Boleści - Chrystusa ukazującego swoje rany, którego prezentuje Maryja, powtarzająca pozę i gest średniowiecznej Matki Bożej Bolesnej. Chrystus jednak, mimo że jest żywy, bez cierniowej korony oraz śladów biczowania na ciele i ma na sobie purpurowy płaszcz i chorągiew zwycięstwa, ciało ma słabe, jakby wymagające podtrzymania. Jest już zmartwychwstały, ale trudno mówić tutaj o triumfującym Zmartwychwstałym. Maryja Bolesna obejmuje Chrystusa lewym ramieniem, prawą ręką podtrzymuje jego prawe ramię, jak często jest to widoczne na średniowiecznych obrazach Misericordia Domini (Dobrzeniecki, „Niektóre zagadnienia"). Postać Maryi w stosunku do średniowiecznego przedstawienia przeszła ideowe przeobrażenie w dobie polemiki kontrreformacyjnej. Podstawową rolę odegrały tutaj przemiany poglądów na rolę Maryi w ekonomii zbawienia. Traktowanie jej jako współuczestniczki w męce Jezusa (compassio), a w konsekwencji także współodkupicielki (corredemptio) przerodziło się w dostrzeżenie jej możliwości w dziedzinie łaski. Towarzyszy 
więc Maryja Chrystusowi już nie tylko jako Mater Dolorosa, ale przede wszystkim jako Mater Misericordiae. Przy wizerunku Chrystusa Zbawiciela Maryja jawi się również jako Pośredniczka (Mediatrix), a szczególnie Causa Salutis (Kałamajska-Saeed 97-110).

Na przedstawieniu znajduje się również obraz Trójcy Świętej, co podkreśla wyraźnie nimb Boga Ojca w kształcie trójkąta. Nie jest to jeden ze średniowiecznych pasyjnych typów, na przykład Tron Łaski. Tam osoby boskie są z sobą ściśle powiązane, a tutaj Bóg Ojciec i Duch Święty znajdują się w innej przestrzeni, niebiańskiej. Obraz ten ma też inną wymowę niż pojawiające się średniowieczu przedstawienia Tronu Laski lub Pietas Domini, rozbudowane, wieloosobowe, jak malowidło malarza środkoworeńskiego z muzeum we Frankfurcie nad Menem, na którym na tle rozległego pejzażu Bóg Ojciec podtrzymuje Chrystusa, a z jego obu stron stoją symetrycznie Maryja, która podnosi prawą dłoń Syna, by ją ucałować, i Jan, który unosi lewą dłoń Jezusa (Dobrzeniecki, „U źródeł przedstawień” 255, il. 25).

Na obrazie przemyskim pięć benedyktyńskich mniszek ukazanych przy Chrystusie całkowicie zmienia wymowę tego malowidła i nakazuje przyjrzeć się istocie Męki Chrystusa w religijności polskiej XVII wieku i roli, jaką odgrywają tutaj przedstawione zakonnice.

Kult Chrystusa cierpiącego, po okresie humanizmu, od drugiej połowy XVI wieku, stał się intensywniejszy, nawiązując często do przejawów religijności średniowiecza (Kopeć, „Nurt pasyjny” 38-60). Znacznie przyczyniły się do tego pełne niepokoju czasy, z ciągłym zagrożeniem wojnami, plagami morowego powietrza i głodem. Kult ten jednak nigdy nie został przerwany. W okresie renesansu powstawały hymny pasyjne (Orzechowski), utrzymało się wiele zwyczajów związanych z zachowywaniem postów i różnymi praktykami religijnymi, wśród nich zalecano odmawianie piętnastu pacierzy na pamiątkę piętnastu ran Pana Jezusa, rozmyślania o siedmiorakim wylaniu krwi Chrystusa, różańce do pięciu ran, pięciu boleści Chrystusa i pięciu boleści Maryi (Górski, Od religijności do mistyki 64).

W XVII wieku zaczęły się mnożyć tłumaczenia małych i dużych Godzinek Męki Pańskiej, powstawały liczne różańce pasyjne i koronki do pięciu ran Pana Jezusa, odmawiane przez cały rok zwłaszcza przez bractwa pod wezwaniami pasyjnymi. Wśród zachowanych tekstów całe bogactwo treści związanej z kultem ran Chrystusa prezentuje Officium o Piąci Ranach Pana, Zbawiciela Naszego, które drukiem ukazało się w Krakowie w 1617 r. na potrzeby zwłaszcza „Bractwa Bożego Ciała, y Piąci plag abo ran Pana naszego Iezvsa Chrystvsa”, działającego przy krakowskim kościele Bożego 
Ciała (Boże, ku wspomożeniu memu wejźrzyj 56-76). Niemalże we wszystkich polskich kościołach odprawiano w piątki Msze św. wotywne o męce, o pięciu ranach Pana lub o krzyżu (Wojtyska 63, 64). Krańcowym przejawem egzystencjalnych postaw wobec męki Chrystusa był w Polsce nawrót publicznego, zbiorowego biczownictwa, wzmożony szczególnie w połowie XVII wieku, w okresie rokoszów, wojen szwedzkich oraz po wojnie północnej i licznych klęskach żywiołowych (Wojtyska 70).

Za najlepszy sposób dojścia do zjednoczenia z Chrystusem cierpiącym uważano medytację. W XVII wieku propagowały ją liczne dzieła drukowane i rękopiśmienne, w dużej części pochodzące od jezuitów. Związana z jezuitami reformatorka i ksieni klasztoru Benedyktynek w Chełmnie Magdalena Mortęska

przez trzy lata tylko o Męce Pańskiej rozmyślała [...] upominała bowiem sama siebie ta panna, naprawując upadłe nabożeństwo w swym klasztorze, onemi słowy: patrzaj, a czyń wedle wizerunku, któryć na górze kalwaryjskiej ukazano. (Górski, Matka Mortęska 120)

Wprowadziła ona też charakterystyczny dla jezuitów sposób odprawiania medytacji. Wiadomo z wielu przekazów, że w klasztorach Kongregacji Chełmińskiej jezuici byli niezmiernie cenieni jako mistrzowie życia duchowego (Borkowska, „Duchowość benedyktynek polskich” 20).

Obraz od przemyskich benedyktynek ukazuje adorację pięciu ran Chrystusa. Nabożeństwo do ran Chrystusa było jednym z najbardziej charakterystycznych przykładów średniowiecznej pobożności pasyjnej. W kręgach monastycznych już od wczesnego średniowiecza rany Chrystusa były uważane za lekarstwo i środek zaradczy na choroby duszy, a także zabezpieczenie przed grzechami i szatanem. Mówi o tym modlitwa z VIII wieku:

Oczyść, o Jezu, ciało i duszę moją z wszelkiej zmazy grzechu, a przez mękę, krzyż i święte rany ciała uwolnij mnie od udręk szatańskich i ciemności piekielnych, zaś przez krew i pogrzeb Twój uzdrów niedomagania moje i wylecz moją ranę serca. (Bonetti 89)

W XII wieku nabożeństwo do ran Chrystusowych otrzymało bogactwo motywów i dynamizm wewnętrzny tak, że uzyskało pozycję dominującą wśród tematów pobożności. Szczególną postacią był wówczas Bernard z Clairvaux (1090-1153), nazywany pierwszym teologiem i apostołem ran Chrystusowych. Przez ukierunkowanie nabożeństwa ku miłosierdziu i miłości Jezusa, przez ranę $\mathrm{w}$ boku doszedł do motywu serca Jezusowego jako symbolu najwyższej miłości (Kopeć, „Męka Pańska” 314-316). 
Nabożeństwo do ran Chrystusa odegrało bardzo ważną rolę w duchowości flamandzkiej mistyczki św. Ludgardy (1182-1246) oraz wielkich mistyczek niemieckich z klasztoru w Helfcie - św. Mechtyldy (1241-1290) i św. Gertrudy (1256-1302). Ich mistyka dała podstawy rozwijającemu się, przede wszystkim w klasztorach, kultowi Serca Jezusa. Chrystocentryczna myśl ich pism reprezentowała żywy w ówczesnej Europie nurt mistyki afektywnej, zwanej również miłosną czy też oblubieńczą (Górecka 93-102). W XIV i XV wieku rany Chrystusa były nazywane znakami miłości, skarbem, ucieczką dusz grzesznych, studnią miłosierdzia Bożego i źródłem zbawczej krwi. Charakterystyczne było powiązanie czci ran Chrystusa z kultem Jego Krwi i Serca (Kopeć, „Męka Pańska” 318, 327).

Duch nabożeństwa do Najświętszego Serca Jezusa bardzo wcześnie przeniknął do Towarzystwa Jezusowego i wiele czerpał z myśli założyciela zakonu, św. Ignacego Loyoli. Zakon ten wydał wielu propagatorów kultu Bożego Serca. Należał do nich między innymi polski jezuita Kasper Drużbicki (1590-1662), autor wielu traktatów, dzieł ascetycznych i modlitewników. Zachęcał on, aby w chwili pokus każdy człowiek szukał „schronienia” w ranach Chrystusa, a szczególnie w ranie boku. W swoim dziele Tractatus de variis Passionem Domini Nostri Jesu Christ meditandi modis, wydanym w Lublinie w 1652 r., pisał, że „krew Jezusa jest «kluczem» otwierającym nam niebo, zamknięte dotąd przez Grzech” (Misiurek, Źródło życia i świętości 46, 50). Jego wrażliwość na mękę Chrystusa i rolę ran, a co za tym idzie - Krwi Pańskiej i kultu Serca Jezusa miała swoją przyczynę nie tylko w rozważaniach tekstów ewangelicznych i patrystycznych, ale również w rozczytywaniu się w dziełach średniowiecznych pisarzy - św. Piotra Damianiego, św. Bernarda z Clairvaux, św. Bonawentury, św. Mechtyldy, św. Gertrudy czy św. Brygidy. Przeświadczenie o cierpieniu, jakie znosiło Serce Jezusa szczególnie podczas męki, ten charakterystyczny dla myśli średniowiecznej rys miłości Bożego Serca, znalazł wyraz w pismach św. Mechtyldy i św. Gertrudy. Podkreślane przez Drużbickiego przeświadczenie o możliwości „transplantacji” Serca Bożego do ludzkiego wnętrza i „zamianie serc” było widoczne w życiu św. Mechtyldy, św. Gertrudy, św. Lutgardy czy św. Katarzyny de Pazzi (Misiurek, Źródło życia i świętości 143, 144)

Podobnie kształtowała się myśl innych polskich teologów, wydaje się jednak, że dla panien benedyktynek jarosławskich, a potem także przemyskich, Kasper Drużbicki był postacią szczególną. Przebywał on bowiem w Jarosławiu, w kolegium jezuickim, dwukrotnie - w 1623 r. na trzeciej probacji oraz w latach 1634-1636 jako instruktor trzeciej probacji. Niewątpliwie, tak 
jak inni jezuici, miał styczność z jarosławskimi benedyktynkami, dla których myśl teologiczna Ignacego Loyoli i innych pisarzy jezuickich, tak jak dla benedyktyńskiej reformatorki Magdaleny Mortęskiej, była niezwykle ważna. W Jarosławiu miał też kontakty z Anną z Kostków Ostrogską, właścicielką miasta i dobrodziejką jarosławskiego konwentu. Tam też napisał swoje dzieło Meta cordium Cor Jesu et SS. Trinitas, wydane w Kaliszu w 1683 r., najgłębiej pouczające o Sercu Jezusowym i jego kulcie. Zazwyczaj nazywano tę książeczkę ,podręcznikiem modlitwy”, ponieważ zawierała wiele rozmyślań, litanii i praktyk ascetycznych przeznaczonych dla ogółu wiernych (Bóg bliski 37). W bibliotece panien benedyktynek w Przemyślu zachował się rękopis z XVII wieku (Sygn. 30 [173]), który prezentuje zbiór medytacji i rozmyślań, a wśród nich Ręka Samego Swętey pamięci X. Drużbickiego pisane, a ztamtad tu przepisane Nauki niektore do uspokoienia sumnienia wielce potrzebne... (Jabłonkowska 92).

Dla myśli teologicznej benedyktynek w XVII wieku ważne były też rozmyślania Magdaleny Mortęskiej. Duchowość, którą przekazywała w swoich naukach, ukazywała elementy wcześniejszych rozważań benedyktyńskich, kształtowane pod wpływem jezuitów. Główną jej cechę stanowiło „bycie z Jezusem" cierpiącym i ukrzyżowanym i branie udziału w Jego cierpieniu. (Borkowska, „Szkic duchowości” 38). Zrozumienie misteriów cierpienia i męki nie było jedynie kwestią intelektu, ale całej jej istoty. Wszystko prowadziło do zjednoczenia z Umiłowanym Chrystusem. Ksieni chełmińska jawi się jako wielka mistyczka, ucząca się teologii z „katedry Krzyża”. Temat misterium Krzyża pojawiał się w rozlicznych jej rozmyślaniach i modlitwach, tak że stała się ona wybitnym piewcą tego tematu. W jej rozmyślaniach o ranach Chrystusa czytamy:

Drugi sposób o św. ranach Chrystusa P[ana] uważanie; do pierwszej rany iść jako chora do lekami [sic!] prosząc tego lekarza niebieskiego, aby On mię nauczuł [sic!] jako mam pozbyć chorób i mizerii [?] moich. Do 2 jako do łaźni [sic!] prosząc aby mnie omul [sic!] z plugastw moich a darował szetami [sic!] ochędożnymi somnienia dobrego. 3. Jako do lekarza, aby On sam doskonale uzdrowiuł [sic!], Do 4 przystępując prosić, aby mnie uzdrobiuł cnotami św. i darami swymi ubogaciuł [sic!]. Do 5 prosić aby mię zamknuł [sic!] w sercu swoi[m]. (Mróz 58)

Przedstawienie na obrazie Adoracja ran Chrystusa przez zakonnice reguty św. Benedykta z przemyskiego klasztoru Panien Benedyktynek reprezentuje właśnie ducha mistyki pasyjnej. W XVII wieku, kiedy powstał obraz, 
duchowość pasyjna była oparta $\mathrm{w}$ dużej mierze na tekstach objawień średniowiecznych wizjonerek, szczególnie św. Mechtyldy i św. Gertrudy z klasztoru w Helfcie. Ich pisma były w XVII wieku wydawane w Polsce. Pierwsze wydanie dzieła św. Mechtyldy i św. Gertrudy w języku niemieckim pochodzi z 1595 r. z Lipska. Wydał je dominikanin Marek z Weidy. Na język polski dzieło św. Mechtyldy przetłumaczył Jakub Gawath, który wydał je we Lwowie w 1645 r. pt. Zwierciadło duchowej taski z dedykacją wojewodziance ruskiej, pannie Dorocie ze Zwrowa Daniłowiczównie, która była ksienią Zakonnic Reguły św. Benedykta Konwentu Lwowskiego przy kościele pod wezwaniem Wszystkich Świętych. Wcześniej ukazało się ono w języku łacińskim w Krakowie w 1639 r. W 1668 r. Marcin z Cochem opublikował w Kaliszu modlitewnik św. Gertrudy i św. Mechtyldy z dodanym pouczeniem o modlitwie ustnej. Ostatnie polskojęzyczne wydanie tych modlitw pochodzi z Chicago z 1918 r. i nosi tytuł Bóg Moja Miłościa (Kowalczyk, Życie i myśl religijna 103-105).

Zjawisko mistycyzmu było bardzo rozpowszechnione w świecie kobiecym. Szczególny rozkwit przeżywało w XIII wieku. W ówczesnej kulturze, kreowanej głównie przez mężczyzn, kobiety znalazły bezpieczną przestrzeń budowania swojego wizerunku i emancypacji religijnej, wyznaczając tym samym nowe drogi do poznania Boga (Künstler-Langner 103-118). Nabożeństwo do człowieczeństwa Jezusa stawało się coraz bardziej powszechne, szczególnie w Niemczech. Chrystus Oblubieniec duszy był tematem poezji mistycznych. Prymat miłości w kontemplacji był cechą charakterystyczną tej oblubieńczej mistyki, zwanej też miłosną (Blasucci 357).

Taki duch, który ujawnia się zarówno w pismach średniowiecznych, jak i w medytacjach siedemnastowiecznych (Kaczor-Scheitler 5-21), jest odczuwalny w przemyskim przedstawieniu Adoracja ran Chrystusa przez zakonnice reguły św. Benedykta. Ukazane zakonnice, poprzez zróżnicowany czas i miejsce życia, reprezentują wielowiekową tradycję i historię zakonu benedyktynek i monastycyzmu benedyktyńskiego opartego na regule św. Benedykta, wskazując na głębokie duchowe korzenie tego zakonu i nieprzerwane jego istnienie.

Święta Scholastyka (480-542), ukazana przy ranie serca Jezusa, bliźniacza siostra św. Benedykta z Nursji, jest uważana za duchową matkę i założycielkę wszystkich żeńskich wspólnot benedyktyńskich, reprezentuje początek zakonu reguły św. Benedykta. Gdy założył on pierwszy klasztor w Subiaco, Scholastyka zainicjowała nieopodal (w Piumarola) działalność podobnej wspólnoty przeznaczonej dla kobiet (Skarga 133-134; Pałubska 1268-1269). 
Monastycyzm francuski VII wieku reprezentuje św. Aldegunda (630684), ukazana przy ranie lewej nogi Chrystusa. Pochodziła z królewskiego rodu Merowingów. Była założycielką i opatką klasztoru reguły św. Benedykta w Maubeuge-sur-Sambre. Jest zaliczana do grona wizjonerek i mistyczek (Keller 27; Kołaczkowski 83)

Na przełomie XII i XIII wieku we Flandrii żyła św. Ludgarda (11821246), przedstawiona przy ranie lewej dłoni Jezusa. Przyszła na świat w bogatej rodzinie w Tongern. W wieku dwunastu lat została oddana na wychowanie do klasztoru św. Katarzyny Aleksandryjskiej w Sint-Truiden. W 1200 r. złożyła profesję zakonną. W 1205 r. wybrano ją przeoryszą. Później przeniosła się do brabanckiego klasztoru w Ayvières. Jej przeżycia mistyczne (od momentu wstąpienia do klasztoru) i duchowość są znane z dzieła Vita (pierwsza redakcja z 1248 r.) flamandzkiego dominikanina Tomasza z Cantimpré (1201-1272) (Sowa 118). Wizja, pierwsza w historii duchowości chrześcijańskiej, rany boku Chrystusa doprowadziła Ludgardę do odkrycia Serca Jezusowego, a także do „wymiany serc”. W jej przeżyciach mistycznych ogromną rolę odegrała idea współcierpienia z Chrystusem. Pragnęła uczestniczyć w cierpieniach Chrystusa i nosić na swoim ciele ślady Jego męki. O jej stygmatyzacji zaświadczyły dwie zakonnice, które dbały o czystość jej stroju zakonnego. Męka Chrystusa i Jego rany stanowiły centrum życia wewnętrznego św. Ludgardy, przez co doszła ona do Serca Jezusa, symbolizującego Jego nieskończoną miłość do ludzi. (Misiurek, Wielkie mistyczki Kościoła 26-31).

Mistykę niemiecką XIII wieku reprezentują dwie święte zakonnice z klasztoru reguły św. Benedykta w Helfcie (Ruh 296-337) - św. Gertruda (1256-1302) przy ranie prawej dłoni i św. Mechtylda (1241-1290) przy ranie prawej stopy. Klasztor początkowo znajdował się w Rodersdorf w diecezji Halberstadt. Nie należał formalnie do zakonu cystersów, choć zachowywał regułę św. Benedykta w interpretacji podobnej do cysterskiej. W $1258 \mathrm{r}$. klasztor przeniesiono do Helfty, małej miejscowości leżącej na południe od Eisleben. Gdy został zburzony w 1342 r., wspólnota przeniosła się właśnie do Eisleben, gdzie wybudowano Nową Helftę, a mniszki, zdając sobie sprawę, że są bardziej benedyktynkami niż cysterkami, zaczęły same określać się mianem mniszek św. Benedykta (Kowalczyk, „Cztery mistyczki” 296-298).

Normą w klasztorze w Helfcie było gruntowne wykształcenie, rozpoczynające się od nauki gramatyki łacińskiej i literatury klasycznej, poprzez teksty liturgiczne, aż po trudne studia teologiczne. Uczennice korzystały też 
z bogatej biblioteki i zajęć muzycznych. Ówczesna ksieni Gertruda von Hackeborn (starsza siostra św. Mechtyldy) za szczególnie ważne uważała studium literackie, bez którego byłoby niemożliwe dobre zrozumienie Pisma Świętego, a to mogłoby się przyczynić do upadku życia monastycznego. Spisane myśli, objawienia i modlitwy Mechtyldy von Hackeborn oraz Gertrudy Wielkiej zyskały szczególną popularność w XVII, a zwłaszcza w XVIII wieku.

Święta Gertruda zwana Wielką urodziła się w Turyngii i w wieku pięciu lat została oddana do klasztoru w Helfcie pod duchowe kierownictwo św. Mechtyldy. Tam zdobyła gruntowne wykształcenie i po złożeniu ślubów pracowała w skryptorium, przepisując i zdobiąc księgi. Dużo czytała: dzieła Ojców Kościoła oraz pisarzy i teologów wczesnego chrześcijaństwa. Od dwudziestego piątego roku życia przeżywała wizje Chrystusa, w których łączyła się z Nim na sposób mistycznych zaślubin (Swastek 1025-1026). Te objawienia i nadzwyczajne łaski św. Gertruda spisała w Zwiastunie Bożej Miłości (Gertruda z Helfty, Zwiastun Bożej) i w Ćwiczeniach (Gertruda z Helfty, Ćwiczenia). W pismach mistyczka zawarła swoje objawienia i medytacje. Dominuje w nich chrystocentryzm, szczególnie człowieczeństwo Chrystusa, co prowadziło do szczegółowego rozpamiętywania Męki Pańskiej i nabożeństwa do Serca Jezusa. Jej przeżycia mistyczne mają w sobie bardzo duży ładunek emocji (Graef 46-56).

Święta Mechtylda pochodziła z Turyngii z jednego z najznamienitszych niemieckich rodów szlacheckich. W wieku siedmiu lat została oddana na wychowanie do klasztoru Cysterek w Rodersdorf, gdzie zakonnicą była jej starsza siostra Gertruda. W 1258 r. klasztor przeniesiono do Saksonii, do Helfty. Tam Mechtylda została kierowniczką szkoły i chóru zakonnego. Miała uzdolnienia muzyczne i piękny głos. Często wykonywała śpiewy liturgiczne (Kowalczyk, „Cztery mistyczki” 295-305; Misiurek, „Mechtylda z Hackeborn” 361). W klasztorze poznała też pisma teologów, szczególnie dominikańskich, gdyż to dominikanie sprawowali kierownictwo duchowe nad zakonnicami z klasztoru w Helfcie. Mechtylda potrafiła łączyć obowiązki z żarliwą modlitwą i głębokim życiem duchowym, którego owocem były nadzwyczajne łaski mistyczne. Jej duchowość była nacechowana pobożnością trynitarną i chrystocentryczną. Maryja zaś była dla niej wzorem i pośredniczką, Tą, która uczy modlitwy i skupienia. Mechtyldę ukształtowała głębia myśli teologicznej św. Augustyna i św. Bernarda z Clairvaux, w człowieku widziała obraz Trójcy Świętej. Według Mechtyldy każda z Osób Trójcy Świętej ma przypisane właściwe sobie działanie: Ojciec - władzę, Syn rozum, Duch Święty - miłość. Chrystusa nazywała „przewodnikiem” lub 
„kluczem” otwierającym dostęp do Trójcy Świętej (Król 140). Te Boskie postaci, jak wiemy, również znalazły miejsce na omawianym malowidle. Często widziała rany Chrystusa, przez których kontemplację dochodziła do rany w boku i Serca Jezusa (Misiurek, Wielkie mistyczki 39-45).

Na przemyskim obrazie atrybutami mniszek są koronki i księgi. Wiążąc koronki z wymową treściową przedstawienia, można domniemywać, że odmawiano na nich modlitwy do pięciu ran Chrystusa. Koronkę do pięciu ran Chrystusa uważa się za bardzo wczesną. Łączono w niej odmawianie pięciu Ojcze nasz (w wersji proponowanej przez św. Franciszka i św. Klarę), pięciu Zdrowaś Maryjo oraz pięciu Chwata Ojcu. W XVII wieku praktykowano rozbudowaną formę tej koronki, szczególnie Bractwa Pięciu Ran Chrystusa (Kopeć, „Koronka” 888). Siostry benedyktynki w klasztorze przemyskim niewątpliwie odmawiały koronkę do Pięciu Ran Chrystusa, o czym świadczy znajdujący się $\mathrm{w}$ tamtejszej bibliotece rękopis z przełomu XVII i XVIII wieku Zbiór modlitw rozmaitych Na Wzbudzenie Ozębłego Ducha y wskrzeszenie nabozeństwa, w którym wśród różnych modlitw znajduje się Koronka do Piaci Ran Chrystusowych (Jabłonkowska 78). Z kolei w zbiorze Złoty ottarz wonnego kadzenia, wydanym w Supraślu w 1760 r., znajduje się tekst rozbudowanej koronki, w której poza tradycyjnymi modlitwami Ojcze nasz, Zdrowaś Maryjo oraz Chwała Ojcu pojawiają się modlitwy do każdej z ran Chrystusa (Złoty Ottarz Wonnego Kadzenia 361-365).

$\mathrm{Na}$ przemyskim obrazie tylko św. Scholastyka jest przedstawiona bez księgi. Stojąc w centrum, przy ranie serca Jezusa, jest niejako symbolem tradycji benedyktyńskiej, ksienią pierwszego klasztoru i co za tym idzie „matką" wszystkich klasztorów żeńskich powstałych według reguły jej bliźniaczego brata, św. Benedykta. W rękopisach przemyskiego klasztoru bardzo często pojawiają się modlitwy do św. Scholastyki i św. Benedykta (Jabłonkowska passim).

Co do ksiąg na obrazie należy też zauważyć bardzo ważny, wydaje się, szczegół, a mianowicie to, że jedna z ksiąg jest otwarta. Znajduje się ona tuż pod postacią Chrystusa, na porośniętym trawą pagórku i należy do św. Mechtyldy, tulącej się do rany w prawej stopie Jezusa (il. 3). „Otwierając" tę księgę, malarz chciał, być może, zwrócić szczególną uwagę na znaczenie dla tego przedstawienia spisanych przeżyć mistycznych właśnie tej świętej, które mogą stanowić źródło dla treści ideowych przemyskiego obrazu.

To św. Mechtylda widziała w swoich objawieniach „Chrystusa chwalebnego, choć upokorzonego w swojej cielesności” (Mechtylda z Hackeborn, 42), 
jak przedstawia to omawiany obraz. Często rozważała Mękę Pana, skupiając się na Jego ranach i z nimi też związane były jej wizje.

Podczas Nieszporny / Obaczyła Pana iakoby z krzyża zdietego; y błogosławiona Panna Marya onego na łonie trzymaiąca / y do niey mowiąca / Przystapiwszy całuy zbawienne Rany naysłodszego Syna mego / które poniosł dla miłości twoiey. Serce iego nayłaskawsze trzy kroć pocałuy / dziekuiąc mu za wypłynienie ono / które od wieku / na ciebie / y na wszystkich wybranych wypłyneło / płynie y wypływać będzie bez końca. (Mechtylda z Hackeborn 64)

Dalej w swoich rozważaniach św. Mechtylda pisze:

Kto częste Meki Pańskiey rospamietywanie odprawować pragnie [...] niech dziekuie Bogu między czym inszym / iż z Rany lewey Nogi iego wypłyneła nam łaźnia zbawienna / a z prawey / rzeka pokoiu: z lewey zaś Reki / wydał nam strumienie łaski; a z prawey lekarstwo Duszne; z Rany także naysłodszego Serca iego / wytoczyła sie nam woda ożywiaiaca y wino upoiaiace / to iest Krew Chrystusa Pana / y wszelkiego dobra obfitość nieprzebrana. (66)

Jak już wspomniano, Maryja była dla św. Mechtyldy pośredniczką, wstawiającą się u Syna za ludźmi. W jednej z wizji właśnie Matka Boża jest ukazana jako ta, która umożliwiła Mechtyldzie pięciokrotne ucałowanie Serca Bożego:

Z Serca zaś Boskiego źródło bardzo przeźroczystej wody wypływało. Dusza tedy przystąpiwszy do Matki Pańskiej prosiła jej, aby otrzymała żeby w tym źródle od wszystkich grzechów mogła być obmyta. Tedy ona łaskawie wziąwszy ją w ręce swoje, przytuliła ją do Serca Boskiego: a ona pięć kroć Serca Jego całowała. W pierwszym pocałowaniu poczuła się być od wszystkich zmaz oczyszczona. W wtórnym, że prawdziwy pokój Boży był jej dan. W trzecim zaś jako przyjaciółka najmilsza osobliwą słodkością udarowana jest. A w czwartym w Serce Boskie porwana jest, gdzie obaczyła i poznała wszystkich wybranych i wszystko stworzenie [...] W piątym zdało się jej, jakoby z Panem u bardzo dostatniego stołu siedziała i z nim biesiadowała. I rzekł Pan: Te pięcioro sposobów Serce moje na każdy dzień całować masz. (Kowalczyk, Życie i myśl religijna 137, 138)

W tym widzeniu zarówno dla Zbawiciela, jak i dla Mechtyldy ważne jest, by pocałunków składanych na Sercu było dokładnie pięć, czyli tyle, ile ran powstało po przebiciu rąk, stóp i boku. Tym samym u mistyczki po raz kolejny do głosu doszła wielowymiarowość biblijnej symboliki liczb, która ma pomóc zrozumieć i ogarnąc całą stworzoną i odkupioną rzeczywistość ludzką. Na obrazie przemyskim na pierwszy plan wysuwa się właśnie pięć ran Chrystusa i pięć pocałunków składanych przez adorujące Chrystusa mniszki.

Pod stopami zakonnic, na pierwszym planie, rozciąga się ogród lub łąka, na której widoczne są różne kwiaty, głównie w kolorach białym (lilie, nar- 
cyzy, konwalie, margarytki i stokrotki) i czerwonym (róże, maki, tulipany, margarytki), a także niebieskim (ostróżki, fiołki). Są one elementami, które towarzyszą mistycznemu zespoleniu z Chrystusem. Tak jak medytacje traktujące o duchowych zaślubinach z Bogiem swoje źródło mają przede wszystkim w Pieśni nad Pieśniami, tak i kwiaty, a zwłaszcza ich najpiękniejsze odmiany, mogą kierować myśl ku nadprzyrodzonemu pięknu, są bowiem ziemskim wyobrażeniem niebiańskiej szczęśliwości. W pismach filozofów i teologów - u Orygenesa (184-253), św. Augustyna (354-430), Pseudo-Dionizego (V/VI w.) czy Hugona ze św. Wiktora (1096-1141) - które nie były obce benedyktynkom, zawarta jest myśl, że rośliny i zwierzęta posiadają w sobie pewne znamiona i symbole spraw niematerialnych (Rotter 103). W Pieśni nad Pieśniami, która obfituje w kwietne metafory, Oblubienica mówi o sobie: „Ja kwiat polny i lilia padolna” (Pnp 2,1). Boski Oblubieniec nazywa swoją wybrankę „lilią między cierniem” (Pnp 2,2). W innym miejscu pieśni jest mowa, że Oblubieniec ,zstąpił do ogrodu swego, / do grządki wonnych ziół, / aby się pasł w ogrodziech / a lilie zbierał" (Pnp 6,1). (Kaczor-Scheitler 9-12). Także Mechtylda w swoich wizjach podaje, jak po czterdziestu dniach choroby ujrzała Chrystusa i spacerowała z nim po łące. (Misiurek, Wielkie mistyczki 43). Kwiaty w symbolice chrystologicznej zwracają uwagę na Jego Boską (białe) i ludzką (czerwone) naturę. Niebieskie wskazują na Jego mękę. Kwiaty są również niezwykle ważne w symbolice maryjnej, zwłaszcza lilie, białe i czerwone róże, a także fiołki. Wszystkie one podkreślają przymioty i cnoty Maryi (Rotter 114, 119). Pejzaż w tle, poza głównym przedstawieniem, przywodzi na myśl rzeczywistość ziemską, w przeciwieństwie do nadprzyrodzonej, budującej główną treść obrazu.

W świątyniach wspólnot zakonnych poprzez głęboko przemyślane dzieła sztuki starano się ukazywać duchowość i historię zakonu. Trudno przypisać takie treści jedynie wiedzy i intelektowi malarza. Musiał on korzystać z rad fundatora czy teologa i umiejętnie przetwarzał jego myśl na język sztuki, przybliżający prawdy wiary, pomagający w kontemplacji, ukazujący wzory świętości.

Święte zakonnice ukazane na omawianym malowidle prezentują, być może, takie przykłady zachowań, a koronki i księgi, w które wyposażył je artysta, wskazują wzorce zachowań dla mniszek oglądających malarskie przedstawienie. Obraz przemyski prezentuje nurt mistyczny w ikonografii. Taki rodzaj przedstawień był kierowany do ludzi, którzy prowadzili pogłębione życie wewnętrzne i mieli już pewne osobiste doświadczenie mistyczne. W takich wypadkach przekaz ikonograficzny miał szanse być właściwie odczytany i zrozumiany. 


\section{BIBLIOGRAFIA}

Blasucci, Antonio. „Mistycyzm kobiecy w średniowieczu”. Historia duchowości, t. IV: Duchowość średniowiecza, red. Benedetto Calati i Reginaldo Gregoire, Homo Dei, 1998, ss. 357-406.

Bonetti,Ignazio. La stimate della passione, Istituto Padano di Arti Grafiche, 1952.

Borkowska, Małgorzata. „Duchowość benedyktynek polskich jako problem badawczy”. Duchowość zakonna. Szkice pod redakcją Jerzego Kłoczowskiego. Wydawnictwo Znak, 1994, ss. 13-23.

Borkowska, Małgorzata. „Magdalena Mortęska zamyślona nad Męką Pańską”. Magdalena Mortęska. Rozmyślania o Męce Pańskiej, wstęp Małgorzata Borkowska i Mirosław Mróz, red. i oprac. Małgorzata Borkowska, Wydawnictwo Benedyktynów, 2020, ss. 11-16.

Borkowska, Małgorzata. „Szkic duchowości benedyktynek Kongregacji Chełmińskiej (1579-1933)”. Duchowość zakonna. Szkice pod redakcją Jerzego Kłoczowskiego. Wydawnictwo Znak 1994, s. 38-50.

Borkowska, Małgorzata. Zakony żeńskie w Polsce w epoce nowożytnej. Instytut Geografii Historycznej Kościoła w Polsce KUL, Wydawnictwo KUL, 2010.

Borkowska, Małgorzata. Życie codzienne polskich klasztorów żeńskich w XVII-XVIII wieku. Państwowy Instytut Wydawniczy, 1996.

Boże, ku wspomożeniu memu wejźrzyj. Godzinki staropolskie, wyd. i wprow. Anna Gąsior i Janusz Królikowski, Uniwersytet Jana Pawła II w Krakowie Wydawnictwo Naukowe, 2017.

Bóg bliski. Historia i teologia Kultu Najświętszego serca Jezusa, red. Czesław Drążek i Ludwik Grzebień, Wydawnictwo Apostolstwa Modlitwy, 1983.

Brzechffa, Stanisław. Najprzewielebniejsza w Bogu panna Magdalena Mortęska, Poznań, druk. S.J., 1747.

Dobrzeniecki, Tadeusz. „Niektóre zagadnienia ikonografii Męża Boleści”. Rocznik Muzeum Narodowego $w$ Warszawie, t. 15, z. 1, 1971, ss. 7-220.

Dobrzeniecki, Tadeusz. „U źródeł przedstawień Tron Laski i Pietas Domini”, Rocznik Muzeum Narodowego w Warszawie, t. 15, z. 1, 1971, ss. 221-312.

Galiński, Placyd. „Duchowość monastyczna”. Duchowość zakonna. Szkice pod redakcja Jerzego Kłoczowskiego. Wydawnictwo Znak, 1994, ss. 24-37.

Gertruda z Helfty. Ćwiczenia. Tłum. Beata Chądzyńska, M. Imelda Rosińska i M. Blandyna Michniewicz, wstęp Małgorzata Borkowska, red. Danuta Zydorek i Jan Andrzej Spież, Wydawnictwo Benedyktynów, 1999.

Gertruda z Helfty. Zwiastun Bożej Miłości. Tłum. Beata Chądzyńska i Emilia Kędziorek, wstęp Małgorzata Borkowska, red. M. Imelda Rosińska, Wydawnictwo Benedyktynów, 2001.

Gosztyła, Marek, i Michał Proksa. Klasztory i zgromadzenia zakonne w Archidiecezji Przemyskiej. Archiwum Państwowe w Przemyślu, Przemyskie Towarzystwo Archiwistyczne „Archiwariusz” w Przemyślu, 2000.

Górecka, Marzena. „Mistyczki z Helfty - ich dzieło i wpływ na europejską kulturę duchową”. Od mistyczki do komediantki. Kobiety Europy epok dawnych - źródta i perspektywy, red. Joanna Godlewicz-Adamiec, Piotr Kociumbas i Małgorzata Sokołowicz, Instytut Germanistyki Uniwersytetu Warszawskiego, 2016, ss. 93-102.

Górski, Karol. Matka Mortęska. Społeczny Instytut Wydawniczy „Znak”, 1971. 
Górski, Karol. Od religijności do mistyki. Zarys dziejów życia wewnętrznego w Polsce. Część pierwsza 966-1795. Towarzystwo Naukowe KUL, 1962.

Górski, Karol. Pisma ascetyczno-mistyczne Benedyktynek reformy chetmińskiej. Jan Jachowski, Księgarnia Uniwersytecka, 1937.

Graef, Hilda. Siedmiobarwna tęcza. Tłum. Stanisław Wilkowski i Irena Gano, Instytut Wydawniczy Pax, 1966.

Hauser, Leopold. Monografia Przemyśla. Przemyśl, Nakładem Księgarni Braci Jeleniów, 1883.

Jabłonkowska, Jolanta Barbara. „Rękopisy Biblioteki Sióstr Benedyktynek w Przemyślu”. Archiwa, Biblioteki i Muzea Kościelne, nr 74, 2000, ss. 65-144.

Kaczor-Scheitler, Katarzyna. „Duchowe zaślubiny z Boskim Oblubieńcem na podstawie siedemnastowiecznych medytacji norbertańskich”. Acta Universitatis Lodziensis. Folia Litteraria Polonica, t. 18, z. 4, 2012, ss. 5-21.

Kałamajska-Saeed, Maria. Ostra Brama w Wilnie. Państwowe Wydawnictwo Naukowe, 1990.

Katalog Zabytków Sztuki w Polsce, t. X: Miasto Przemyśl, red. Jakub Sito, cz. 1: Zespoły sakralne, oprac. Piotr Krasny i Jakub Sito, Instytut Sztuki Polskiej Akademii Nauk, 2004.

Keller, Hiltgart. Reclams Lexikon der Heiligen und der biblischen Gestalten. Legende und Darstellung in der bildenden Kunst. Philipp Reclam Jun., 1975,

Kieferling, Krystyna. „Kościół i klasztor PP Benedyktynek w Jarosławiu. Rys historyczny”. Przemyskie Zapiski Historyczne, nr 12/13, 2000/2002, ss. 193-220.

Kobielus, Stanisław. „Reguły estetyki benedyktyńskiej według traktatu Teofila Prezbitera Diversarum Artium Schedula”. Dzieło sztuki dzieło wiary, Apostolicum. Wydawnictwo Księży Pallottynów, 2002, ss. 246-261.

Kołaczkowski, Andrzej. „Adelgunda”. Encyklopedia katolicka, t. 1, Towarzystwo Naukowe KUL, 1973, kol. 83.

Kopeć, Józef J.. „Koronka”. Encyklopedia katolicka, t. 9, Towarzystwo Naukowe KUL, 2002, kol. 886-892.

Kopeć, Józef J. „Męka Pańska w religijnej kulturze polskiego średniowiecza. Studium nad pasyjnymi motywami i tekstami liturgicznymi”. Textus et Studia, nr 3, 1975.

Kopeć, Józef J. „Nurt pasyjny w średniowiecznej religijności polskiej”. Męka Chrystusa wczoraj $i$ dziś, red. Henryk D. Wojtyska i Józef J. Kopeć, Redakcja Wydawnictw KUL, 1981, ss. 38-60.

Kowalczyk, Marta. „Cztery mistyczki, dwa imiona i jeden klasztor”, Studia Warmińskie, nr 46, 2009, s. 295-305.

Kowalczyk, Marta. Życie i myśl religijna św. Mechtyldy von Hackeborn. Flos Carmeli, 2011.

Król, Lech. „Elementy treściowe doświadczeń mistycznych św. Mechtyldy von Hackeborn”. Studia Wloctawskie, nr 18, 2016, ss. 139-154.

Künstler-Langner, Danuta. „Kobiety wobec doświadczeń mistycznych (od średniowiecza do XVII wieku)". Od mistyczki do komediantki. Kobiety Europy epok dawnych - źródła i perspektywy, red. Joanna Godlewicz-Adamiec, Piotr Kociumbas i Małgorzata Sokołowicz, Instytut Germanistyki UniwersytetuWarszawskiego, 2016, ss. 103-118.

Mechtylda z Hackeborn. Zwierciadło dvchowney łaski, to iest: Dziwne cudowney pannie, zakonnicy, y xieniey Reguty Benedykta S. Zakonnic w Oetilstetynie, w Saskiey Ziemi Mechtildzie S. w vstawiczney bogomyslnosci trwaiacey niebieskie obiawienia. Do dostapienia dokonałośći chrześćiańskiey barzo pożyteczne. Na pięc części rozdźielone, z Przydatkiem o żywocie y smierći Giertrvdy S. rodzoney teyże Mechtildy S. siostry / y z Zywotem samey 
Mechtildy S. nowo wynalezionym. Lwów, W Drukarni Coleg: Societ: Jesu, u Sebastyana Nowogorskiego, 1645.

Misiurek, Jerzy. „Mechtylda z Hackeborn”. Encyklopedia katolicka, t. 12, Towarzystwo Naukowe KUL, 2008, kol. 361.

Misiurek, Jerzy. Wielkie mistyczki Kościoła. Redakcja Wydawnictw KUL, 1999.

Misiurek, Jerzy. Źródło życia i świętości. Polska teologia kultu Najświętszego Serca Jezusa. Towarzystwo Naukowe KUL, 2014.

Mróz, Mirosław. „Duchowość pasyjna Magdaleny Mortęskiej w świetle pism benedyktynem reformy chełmińskiej”. Magdalena Mortęska. Rozmyślania o Męce Pańskiej, wstęp Małgorzata Borkowska i Mirosław Mróz, red. i oprac. Małgorzata Borkowska, Wydawnictwo Benedyktynów, 2020, ss. 17-64.

Orzechowski, Stanisław. Wybór pism, oprac. Jerzy Starnawski, Zakład Narodowy im. Ossolińskich. Wydawnictwo, 1972.

Pałubska, Zofia. „Scholastyka”. Encyklopedia katolicka, t. 17, Towarzystwo Naukowe KUL, 2012, kol. 1268-1269.

Rotter, Lucyna. Duchowość i historia benedyktynek w symbolice dekoracji malarskiej kościoła w Staniatkach. Wydawnictwo Naukowe PAT, 2004.

Ruh, Kurt. Frauenmystik und Franziskanische Mystik der Fahrenheit. Verlag C.H. Beck, 1993.

Skarga, Piotr. Żywoty Świętych Pańskich Starego i Nowego Zakonu..., Petersburg, Nakład i druk Bolesława Maurycego Wolffa, 1862 (reprint: Gutenberg-Print, 1996).

Sowa, Franciszek. „Ludgarda”. Encyklopedia katolicka, t. 11, Towarzystwo Naukowe KUL, 2006, kol. 118.

Swastek, Józef. „Gertruda Wielka”. Encyklopedia katolicka, t. 5, Towarzystwo Naukowe KUL, 1989, kol. 1025-1026.

Szołdrski, Władysław. Kronika benedyktynek chetmińskich. Nakładem Kurii Biskupiej Czcionkami Drukarni i Księgarni SP. Z O.O., 1937.

Teofil Prezbiter. Diversarum Artium Schedula i inne średniowieczne zbiory przepisów o sztukach rozmaitych. Tłum. i oprac. Stanisław Kobielus, Wydawnictwo Benedyktynów, 2009.

Wojtyska, Henryk D. „Męka Chrystusa w religijności polskiej XVI-XVIII wieku”. Męka Chrystusa wczoraj i dziś, red. Henryk D. Wojtyska i Józef J. Kopeć, Redakcja Wydawnictw KUL, 1981, ss. 61-79.

Złoty Ottarz Wonnego Kadzenia Przed Stolica Boża. To iest Modlitwy Rozmaite Kośćiołowi S. Zwyczayne, Ktore Duch goracy P. Bogu na Ewonność Stodkośći Chwaty iego ofiarować może. Za Dozwoleniem Zwierzchności Duchowney Przedrukowane W Supraslii W Drukarni WW. XX. Bazylianow roku Pańskiego 1760.

\section{TRZYNASTOWIECZNA TRADYCJA MISTYCZNA \\ W BAROKOWYM OBRAZIE ADORACJI RAN CHRYSTUSA PRZEZ ZAKONNICE REGUŁY ŚW. BENEDYKTA \\ Z KLASZTORU PANIEN BENEDYKTYNEK W PRZEMYŚLU}

Streszczenie

W klasztorze Panien Benedyktynek w Przemyślu znajduje się siedemnastowieczny obraz ukazujący adorację Chrystusa przez zakonnice reguły św. Benedykta. Przedstawienie to reprezentuje 
ducha mistyki pasyjnej. W XIII wieku nabożeństwo do człowieczeństwa Jezusa stawało się coraz bardziej powszechne, szczególnie w Niemczech. Prymat miłości w kontemplacji był cechą charakterystyczną tej mistyki oblubieńczej, zwanej też miłosną. W XVII wieku, w czasie kiedy powstał obraz, duchowość pasyjna kontynuowała myśl średniowieczną i oparta była w wielkiej mierze na tekstach objawień średniowiecznych wizjonerek, szczególnie św. Mechtyldy z Heckeborn i św. Gertrudy Wielkiej. Ogromną rolę w rozwoju kultu Męki Chrystusa i Jego Serca na ziemiach polskich odegrali wówczas ksieni benedyktynek chełmińskich Magdalena Mortęska i jezuita Kasper Drużbicki. Ukazane na obrazie zakonnice, poprzez zróżnicowany czas i miejsce życia, reprezentują także wielowiekową tradycję i historię zakonu benedyktynek i monastycyzmu benedyktyńskiego.

Slowa kluczowe: malarstwo barokowe; benedyktynki; mistyka średniowieczna; pobożność potrydencka; Magdalena Mortęska; Kasper Drużbicki.

\author{
THE THIRTEENTH-CENTURY MYSTICAL TRADITION \\ IN THE BAROQUE PAINTING THE ADORATION OF CHRIST'S WOUNDS \\ BY NUNS OF THE ORDER OF ST. BENEDICT \\ IN THE BENEDICTINE CONVENT IN PRZEMYŚL
}

\title{
Su m m ary
}

This paper looks at the 17th-century painting showing the adoration of Christ by nuns of the Order of St. Benedict, and which is to be found in the Convent of the Benedictine Sisters in Przemyśl. This depiction represents the spirit of the mysticism of the Passion. In the 13th century, devotion to the humanity of Jesus became more and more common, especially in Germany. The primacy of love in contemplation was a characteristic feature of this bridal mysticism, which was also known as love mysticism. In the 17th century, when the painting was created, this passionate spirituality continued this line of medieval thought, which was largely based on the texts of the revelations of medieval visionaries, especially those of St. Mechthild of Hackeborn and St. Gertrude the Great. A considerable role in the development of the cult of the Passion of Christ and His Heart in Poland was played by the prioress of the Benedictine nuns of Chełmno, Magdalena Mortęska, and the Jesuit Kasper Drużbicki. The nuns who are shown in the picture, from various times and places, represent the centuries-old tradition and history of the Benedictine Order and Benedictine monasticism.

Keywords: baroque painting; Benedictine nuns; medieval mysticism; post-Tridentine piety; Magdalena Mortęska; Kasper Drużbicki. 


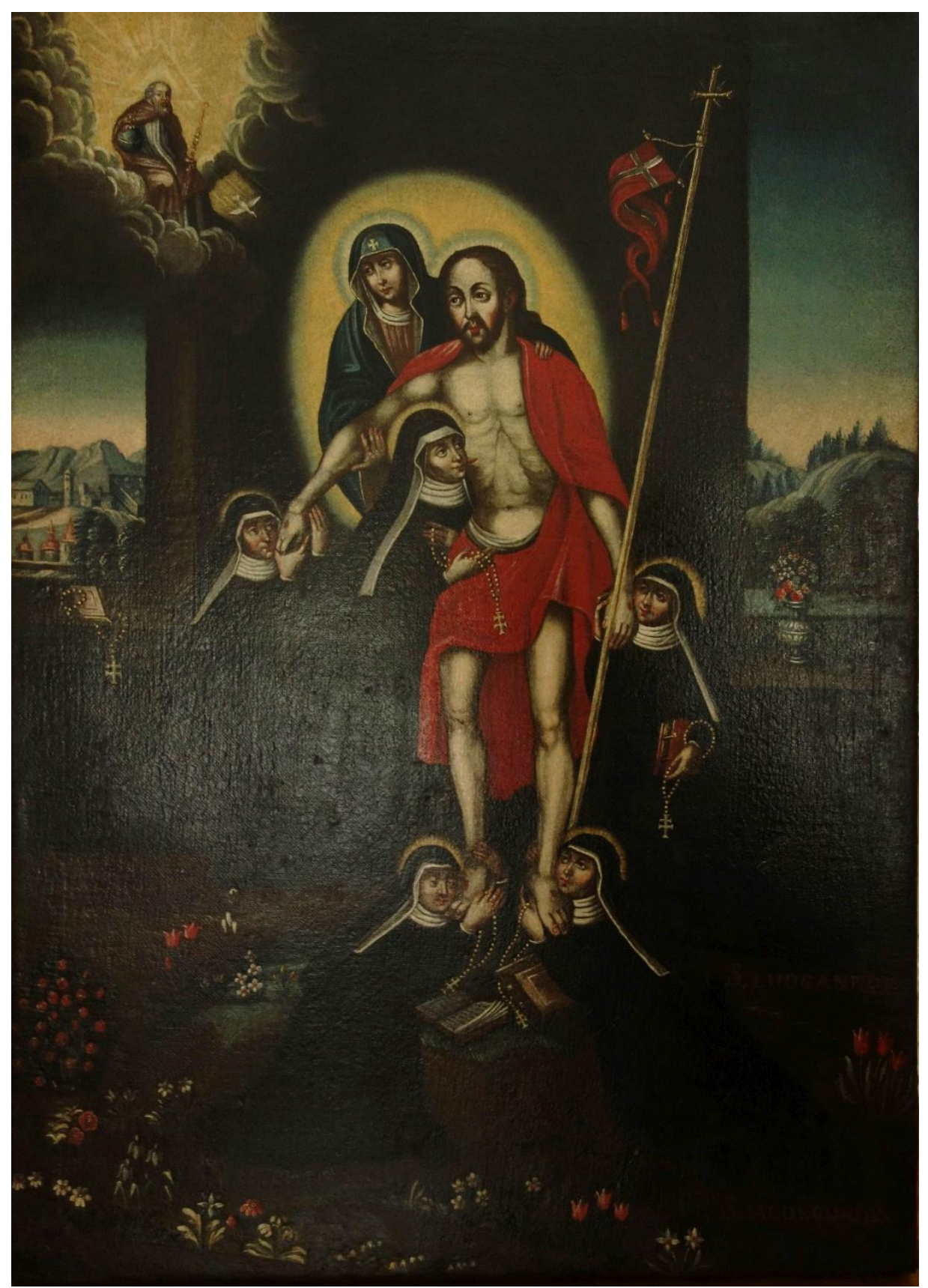

1. Adoracja Ran Chrystusa przez zakonnice reguły św. Benedykta, poł. XVII wieku, Przemyśl, klasztor Panien Benedyktynek, fot. ks. P. Lasota 


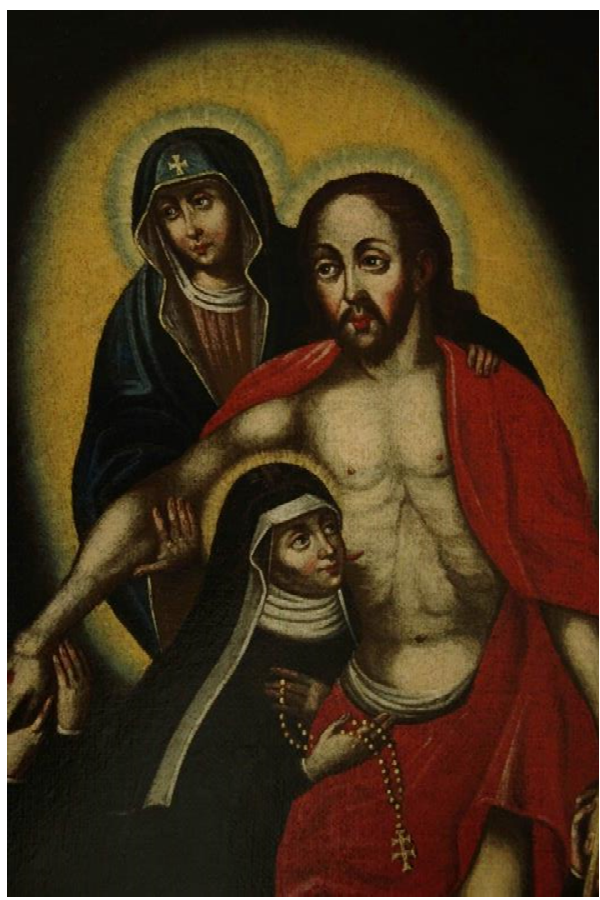

2. Adoracja Ran Chrystusa przez zakonnice reguly św. Benedykta (fragment), poł. XVII wieku, Przemyśl, klasztor Panien Benedyktynek, fot. ks. P. Lasota

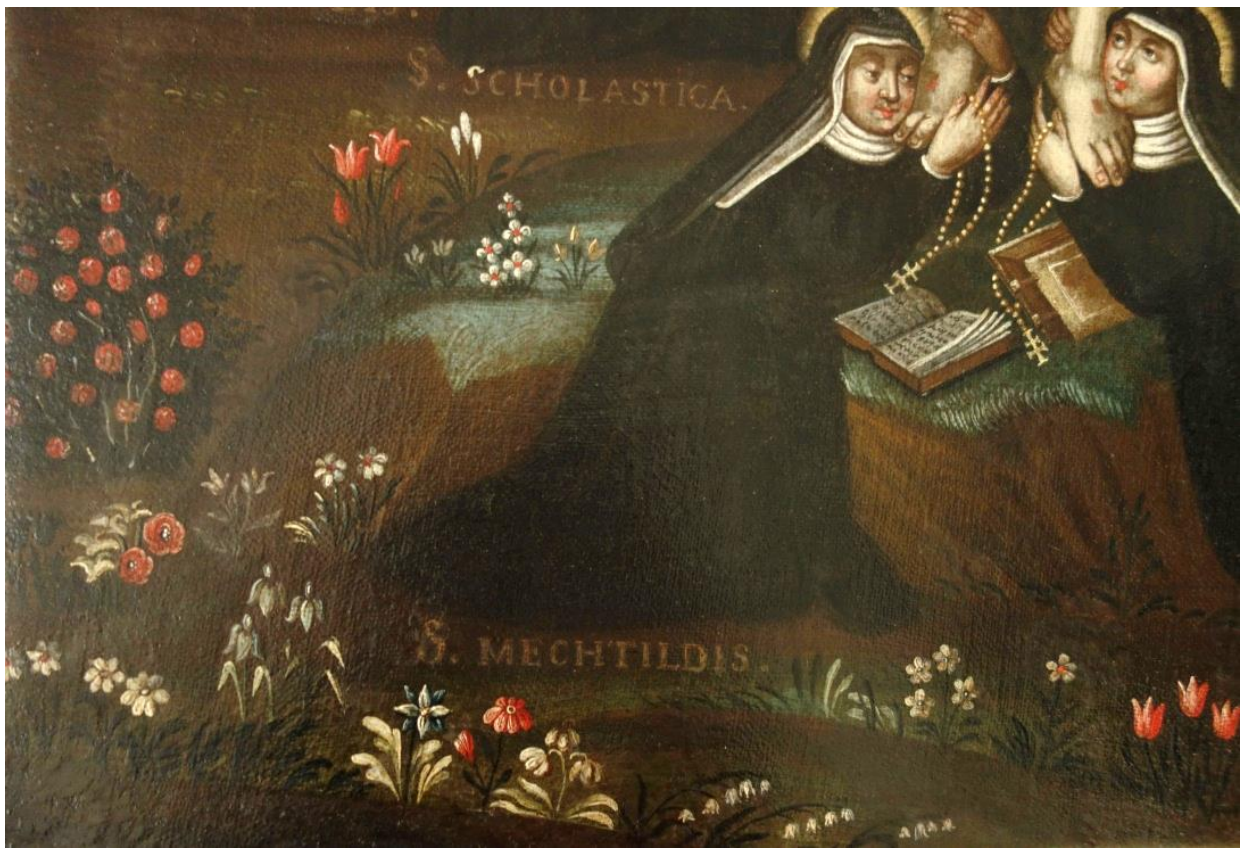

3. Adoracja Ran Chrystusa przez zakonnice reguly św. Benedykta (fragment), poł. XVII wieku, Przemyśl, klasztor Panien Benedyktynek, fot. ks. P. Lasota 


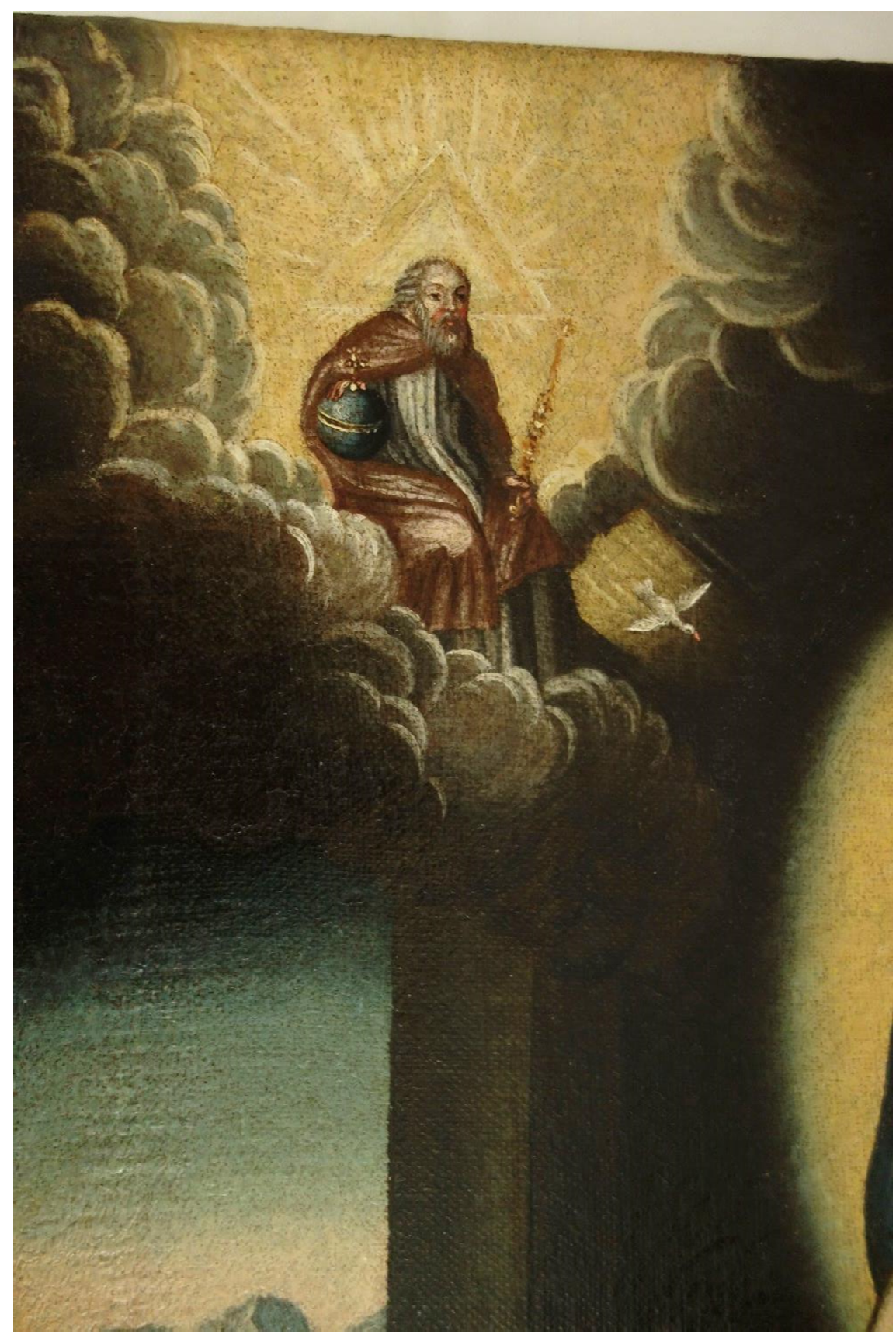

4. Adoracja Ran Chrystusa przez zakonnice reguly św. Benedykta (fragment), poł. XVII wieku, Przemyśl, klasztor Panien Benedyktynek, fot. ks. P. Lasota 